\title{
Isotopes features of the intrusive rocks in the Xigaze ophiolite, southern Tibet: Constraints on its formation setting
}

\author{
Liang-Liang Zhang ${ }^{12}$, Chuan-Zhou Liu' ${ }^{2}$, Wu-Yuan \\ $\mathrm{Wu}^{2}$, Chang Zhang ${ }^{2}$, Wei-Qiang $\mathrm{Ji}^{2}$, Jian-Gang Wang ${ }^{2}$ \\ 1 Institute of Earth Sciences, China University of \\ Geosciences, Beijing 100083, China \\ 2 State Key Laboratory of Lithospheric Evolution, Institute of \\ Geology and Geophysics, Chinese Academy of Sciences, \\ Beijing 100029,China
}

The Xigaze ophiolite is best exposed at the central part of the Yarlung-Zangbo Suture Zone, Tibet Plateau. It consists of a thick section of mantle peridotites, but a relatively thin mafic sequence, which contain rodingites, gabbros, diabases, basalts and plagiogranites. The rodingites are characterized by high $\mathrm{CaO}$ and low $\mathrm{Na}_{2} \mathrm{O}$ contents. Gabbros, diabases and basalts display REE patterns similar to N-MORB. The plagiogranites have compositions of trondhjemite to tonalite. Zircons from seven samples have been dated and yielded $\mathrm{U}-\mathrm{Pb}$ ages of $124.6 \sim 130.5 \mathrm{Ma}$. They have mantle-like $\delta^{18} \mathrm{O}$ values of $+4.92 \sim+5.26 \%$ and very positive $\varepsilon_{\mathrm{Hf}}(\mathrm{t})$ values of $+16 \sim+13.3$. Occurrence of both gabbroic and diabase dykes within the serpentinites suggests that the mantle lithosphere of the Xigaze ophiolite was rapidly exhumed. Both mafic and felsic dykes have slightly more radiogenic ${ }^{87} \mathrm{Sr} /{ }^{86} \mathrm{Sr}$ ratios relative to MORB, but depleted $\mathrm{Hf}-\mathrm{Nd}$ isotope compositions. They have a limited range of $\varepsilon \mathrm{Nd}(\mathrm{t})$ values of $+7.9 \sim+8.9$ but variable $\varepsilon \mathrm{Hf}(\mathrm{t})$ values ranging from +9.9 to +16.7 , which are similar to the global MORB . We apply the forearc hyperextension model to reconcile the occurrence of both MOR- and SSZ-type basalts in the Xigaze ophiolite. In this model, the SSZ-type basalts were produced by melting of the metasomatized mantle wedge during exhumation, whereas the MOR-type basalts were derived from the upwelling asthenosphere triggered by forearc hyperextension. 